\title{
Tumor Necrosis Factor and Reactive Oxygen Species Cooperative Cytotoxicity Is Mediated via Inhibition of NF- $\kappa$ B
}

\author{
Irene Ginis, John M. Hallenbeck, Jie Liu, Maria Spatz, Rama Jaiswal, \\ and Esther Shohami \\ Stroke Branch, National Institute of Neurological Disorders and Stroke, NIH \\ Bethesda, Maryland, U.S.A.
}

Accepted August 1, 2000.

\begin{abstract}
Background: Tumor necrosis factor alpha ( $\mathrm{TNF} \alpha)$ plays a key role in pathogenesis of brain injury. However, TNF $\alpha$ exhibits no cytotoxicity in primary cultures of brain cells. This discrepancy suggests that other pathogenic stimuli that exist in the setting of brain injury precipitate $\mathrm{TNF} \alpha$ cytotoxicity. The hypothesis was tested that reactive oxygen species (ROS), that are released early after brain injury, act synergistically with TNF $\alpha$ in causing cell death.

Materials and Methods: Cultured human and rat brain capillary endothelial cells (RBEC), and cortical astrocytes were treated with $\mathrm{TNF} \alpha$ alone or together with different doses of $\mathrm{H}_{2} \mathrm{O}_{2}$, and apoptotic cell death and DNA fragmentation were measured by means of 3'-OH-terminal deoxynucleotidyl transferase-mediated dUTP nick end labeling (TUNEL) and Hoechst fluorescence assay, respectively. The effect of $\mathrm{H}_{2} \mathrm{O}_{2}$ on TNF $\alpha$-induced activation of nuclear factor kappa B $(\mathrm{NF}-\kappa \mathrm{B})$ was measured by Western
\end{abstract}

blots of cytoplasmic and nuclear extracts of RBEC using anti-inhibitor of NF- $\kappa \mathrm{B}(\mathrm{I} \kappa \mathrm{B})$ and anti-p65 subunit of NF- $\kappa \mathrm{B}$ antibodies. Nuclear translocation of NF- $\kappa \mathrm{B}$ was investigated by immunofluorescent staining of RBEC with anti-p65 antibodies.

Results: TNF $\alpha$ alone had no cytotoxic effect in brain endothelial cells and astrocytes at concentrations up tol00 ng/ml. Co-treatment with $5-10 \mu \mathrm{M}$ of $\mathrm{H}_{2} \mathrm{O}_{2}$ caused a two-fold increase in the number of apoptotic cells $24 \mathrm{hr}$ later. Similar doses (1-3 $\mu \mathrm{M})$ of $\mathrm{H}_{2} \mathrm{O}_{2}$ initiated early DNA fragmentation. $\mathrm{H}_{2} \mathrm{O}_{2}$ inhibited TNF $\alpha$-induced accumulation of p65 in the nucleus, although it had no effect on degradation of the $\mathrm{I} \kappa \mathrm{B}$ in cytoplasm. Immunostaining confirmed that $\mathrm{H}_{2} \mathrm{O}_{2}$ inhibited p65 transport to the nucleus.

Conclusions: Reactive oxygen species could act synergistically with TNF $\alpha$ in causing cytotoxicity via inhibition of a cytoprotective branch of TNF $\alpha$ signaling pathways, which starts with NF- $\kappa \mathrm{B}$ activation.

\section{Introduction}

The pleiotropic cytokine tumor necrosis factor alpha $(\mathrm{TNF} \alpha)$ exerts biological activity in CNS (1-4). TNF $\alpha$ effects in brain parenchyma are shown to play a key role in brain injury (5-8). High TNF $\alpha$ levels have been detected in brain

\footnotetext{
Address correspondence and reprint requests to: Irene Ginis, Senior Staff Fellow, Stroke Branch, NINDS, NIH, Building 36, Room 4A03, Bethesda, MD 20892-4128. Phone: 301-435-7655; Fax: 301-402-2769; E-mail: ginisi@ninds.nih.gov

Esther Shohami was a Visiting Professor at SB NINDS; her permanent address is: Department of Pharmacology, The Hebrew University School of Pharmacy, Jerusalem, Israel.
}

trauma (9-11) and ischemia (12-15). Neutralization of TNF $\alpha$ by $\mathrm{TNF} \alpha$-binding protein had a protective effect against focal ischemia $(16,17)$ and trauma (18) and an inhibitor of $\mathrm{TNF} \alpha$ synthesis, dexanabinol has a protective effect in closed head injury (CHI) and MCAO $(19,20)$.

However, in vitro studies demonstrate that $\mathrm{TNF} \alpha$ is not cytotoxic in brain cells. It even causes protection of cultured neurons (21-23). Cultured cortical astrocytes and brain endothelial cells treated with TNF $\alpha$ for $48 \mathrm{hr}$ exhibit no signs of apoptosis (24). The discrepancy between observations of a TNF $\alpha$ pathogenic 
function in animal models of brain injury and its lack of cytotoxic effect on brain cells in vitro suggests that other pathogenic stimuli contribute to $\mathrm{TNF} \alpha$ cytotoxicity in the setting of brain injury.

Reactive oxygen species are among the most toxic mediators released early after brain injury. The brain is extremely vulnerable to oxidative damage (25). We have shown that the synthetic spin-trap antioxidant from the nitroxide family, Tempol, improved recovery and protected the blood-brain barrier in a rat model of CHI (26). Similar protection was found after $\mathrm{CHI}$ in heat-acclimated rats, in which the endogenous antioxidants have been shown to be elevated (27). On the other hand, TNF $\alpha$ levels and activity were not affected in Tempol-treated or heat-acclimated animals (28), suggesting that ROS could alter TNF $\alpha$ signaling rather than TNF $\alpha$ synthesis and thus precipitate TNF $\alpha$ cytotoxicity. Similarly, the same spin-trap molecule, was used in studies of bacterial and cultured mammalian cells and was shown to provide cytoprotection from the toxicity induced by TNF $\alpha$ (29). Transcription of many pro-inflammatory, immune, and apoptotic genes, which are induced by $\mathrm{TNF} \alpha$, is dependent on activation of nuclear factor kappa $B$ $(\mathrm{NF}-\kappa \mathrm{B})$. Each step of NF- $\kappa \mathrm{B}$ activation and DNA binding is redox sensitive (30). Taken together, these observations suggest that the point of intersection of TNF $\alpha$ and ROS, which both accompany brain insults, could be NF$\kappa \mathrm{B}$. The present study was designed to test this hypothesis. We demonstrate here that sublethal doses of $\mathrm{H}_{2} \mathrm{O}_{2}$ abrogate natural resistance of different types of brain cells to TNF $\alpha$ by inhibiting TNF $\alpha$-induced activation of NF- $\kappa \mathrm{B}$.

\section{Materials and Methods}

Human brain capillary endothelial cells (HBEC) cultures have been previously described (31). Rat brain capillary endothelial cells (RBEC) were prepared from adult WKY rat brains as for human cultures except that fetal bovine serum was substituted for human serum and $90 \mu \mathrm{g} / \mathrm{ml}$ heparin was added to the medium. The purity of the both HBEC and RBEC was $>95 \%$ as determined by positive immunostaining for von Willebrand factor (Factor VIII), and angiotensin-converting enzyme, incorporation of acetylated low-density lipoprotein, and by negative staining for glial cells (GFAP, galactocerebroside, ED-2), muscle cells ( $\alpha$-actin) and pericytes (tropomyosin). Human brain capillary endothelial cells were at passage 4. Rat brain capillary endothelial cells were at passages 7-12 and were seeded from four different batches of brain tissue. Cortical astrocyte cultures were established from 3-day-old Sprague-Dawley rats as described (24).

Visualization and quantitation of apoptotic cells was performed by means of $3^{\prime}-\mathrm{OH}$-terminal deoxynucleotidyl transferase-mediated dUTP nick end labeling (TUNEL) using "In Situ Cell Death Detection Kit (POD)" (Boehringer Mannheim, Germany). Human brain capillary endothelial cells and RBEC were treated with $15 \mathrm{ng} / \mathrm{ml}$ human TNF $\alpha$ (Endogen, Woburn, MA, USA) and $20 \mathrm{ng} / \mathrm{ml}$ rat TNF $\alpha$ (Chemicon International Inc., Temecula, CA, USA), respectively, or/and with different doses of $\mathrm{H}_{2} \mathrm{O}_{2}$ for $24 \mathrm{hr}$, fixed with $4 \%$ paraformaldehyde for $30 \mathrm{~min}$ and stained according to the manufacture's protocol. The samples were analyzed with a Zeiss Axiovert 100 light microscope (20× objective). Digitized images of 15 microscopic fields per each experimental condition were generated using a digital CCD Camera C4742-95-12 (Hamamatsu) and Zeiss AxioVersion 2 software. The same microscope and camera settings were used for all samples. The number of apoptotic cells within each image was determined by means of Scion Image (NIH Image for PC) computer program. Briefly, background was subtracted from each image and each image was transformed into a binary image, which permitted measurement of the area occupied by all of the cells in the image $(\operatorname{area} \mathrm{T})$. All the images were then reversed to multi-gray mode, and the average optical density of nonstained cells was measured for all images acquired. The value of the mean density of nonstained cells was subtracted from all the images and the remaining areas of higher density (area A) (these were positively stained apoptotic nuclei) were again thresholded to binary images and measured.

Percentage of apoptotic cells was calculated as follows:

$$
\% \text { apoptotic nuclei }=\frac{r A}{\mathrm{~T}} * 100
$$

where: $A$ is the sum of the TUNEL-positive areas in the image, and $T$ is the sum of the areas 
occupied by all cells in the image.

$$
\begin{gathered}
r=\frac{\text { size of the cell }}{\text { average size of the nucleus }} ; \\
r=3.25 \pm 0.75(n=15)
\end{gathered}
$$

Quantitation of DNA fragmentation was performed by means of a fluorescent, cellpermeable, DNA-binding dye, Hoechst 33342 as previously described (24). Hoechst fluorescence upon binding to DNA is inversely proportional to the degree of DNA fragmentation in the cells undergoing apoptosis (32). Briefly, $\mathrm{TNF} \alpha / \mathrm{H}_{2} \mathrm{O}_{2}$-treated astrocytes or RBEC, plated in 96 well microtiter plates were incubated with $25 \mu \mathrm{M}$ Hoechst 33342 (Molecular Probes, Eugene, OR, USA) in PBS added at $100 \mu \mathrm{l} /$ well for $45 \mathrm{~min}$ at $37^{\circ} \mathrm{C}$. Cell fluorescence was measured using a CytoFluor 4000 fluorescent plate reader (PerSeptive Biosystems, Framingham, MA, USA) at excitation/emission wavelengths of 360/460 nm. Background fluorescence was measured on each plate and subtracted. Each data point was a mean of fluorescence readings of eight wells (variability was less than $30 \%$ ). The percentage of apoptotic cells was calculated from Hoechst fluorescence by means of the following formula:

$$
\% \text { apoptotic cells }=\frac{F \max -F}{F \max -F \min } * 100 \%
$$

where $F_{\max }$ is fluorescence of untreated healthy control cultures, $F_{\min }$ is fluorescence of cells treated with the cytotoxic alkylating agent methyl iodide, and $F$ is fluorescence of unknown sample.

\section{Immunofluorescent Staining for $p 65$ \\ Subunit of NF- $\kappa B$}

Endothelial cells were treated with $20 \mathrm{ng} / \mathrm{ml}$ $\mathrm{TNF} \alpha$ and with or without various doses of $\mathrm{H}_{2} \mathrm{O}_{2}$ for $25 \mathrm{~min}$. Cells were fixed with ethanol for $2 \mathrm{~min}$ and then with $3.7 \%$ formaldehyde for $5 \mathrm{~min}$ and immunostained with rabbit polyclonal antibody directed against the p65 subunit of NF- $\kappa$ B (Santa Cruz, cat. \#sc109) or with mouse monoclonal antibody against the activated form of p65 (Boehringer-Manheim Cat. \#1697838) both antibodies were at 1:50 dilution according to Kaltschmidt et al. (69). Detection was performed with anti-rabbit and anti-mouse corresponding biotinylated secondary antibody, followed by addition of streptavidin-Cy3. Digitized images of the fluorescent cells were generated using the same microscope and camera as for TUNEL experiments $(40 \times$ objective) .

\section{Preparation of Cytosolic and Nuclear Extracts}

Rat brain capillary endothelial cells were grown to confluency in $60-\mathrm{mm}$ dishes. Rat TNF $\alpha$ (Chemicon International, Temecula, CA, USA) was added to the cells at $20 \mathrm{ng} / \mathrm{ml}$ with or without $2 \mu \mathrm{M} \mathrm{H}_{2} \mathrm{O}_{2}$. At the indicated times, cells were placed on ice, washed twice with PBS, and then scraped off into 800- $\mu$ l PBS containing protease inhibitor cocktail (Boehringer Mannheim), phosphatase inhibitors (10 mM $\mathrm{NaF}, 1 \mathrm{mM} \mathrm{Na} \mathrm{VO}_{4}$ ), and $1 \mathrm{mM}$ dithiothreitol (DTT). Cells were pelleted in a microcentrifuge for $1 \mathrm{~min}$ at $2,500 \mathrm{rpm}$, resuspended in 5 volumes $(\sim 100 \mu \mathrm{l} /$ dish $)$ of a low salt buffer $A$ (10 mM HEPES, $10 \mathrm{mM} \mathrm{KCl,} 0.1 \mathrm{mM}$ EDTA, $0.1 \mathrm{mM}$ EGTA, $\mathrm{pH}=7.9$ ) and incubated for 15 min on ice. At the end of incubation NP-40 was added to the lysates at final concentration $0.1 \%$. Samples were vigorously vortexed for $20 \mathrm{sec}$ and centrifuged at $11,000 \mathrm{rpm}$ for $1 \mathrm{~min}$. Cytoplasmic fraction was transferred to a new Eppendorf tube, and frozen at $-70^{\circ} \mathrm{C}$. The pellet was resuspended in 30-50 $\mu \mathrm{l} / \mathrm{dish}$ high salt buffer B (20 mM HEPES, $400 \mathrm{mM} \mathrm{NaCl}$, $50 \mathrm{mM} \mathrm{KCl}, 1 \mathrm{mM}$ EDTA, $1 \mathrm{mM}$ EGTA, 10\% $(\mathrm{w} / \mathrm{v})$ glycerol, $\mathrm{pH}=7.9)$. The samples were shaken at a high speed for $30 \mathrm{~min}$ and then microcentrifuged at $14,000 \mathrm{rpm}$ for $5 \mathrm{~min}$. The supernatant was frozen at $-70^{\circ} \mathrm{C}$. Prior to freezing, a $2-\mu \mathrm{l}$ aliquot from each cytosolic and nuclear extract was taken for protein determination (Bio-Rad Laboratories, Hercules, CA, USA). All reagents were ice-cold, and all procedures were performed on ice.

\section{Western Blots for NF- $\kappa B$ Studies}

All the buffers, 4-12\% Tris-glycine gradient mini-gels, nitrocellulose membranes, and electrophoresis equipment were from Novex (San Diego, CA, USA). Cytosolic or nuclear extracts were boiled in equal volumes of loading buffer/1 mM DTT for 3 min and loaded on a gel at $10 \mu \mathrm{g}$ protein/lane for determination of $\mathrm{p} 65$ concentrations in nuclear extracts, and at $15 \mu \mathrm{g}$ protein/lane for $\mathrm{I} \kappa \mathrm{B}$ determination in cytosolic fractions. Separated proteins were transferred to nitrocellulose membrane. Immunoblotting was performed as previously described (33). Anti- $\mathrm{I} \kappa \mathrm{B} \alpha$ and anti-p65 rabbit polyclonal antibodies were from Santa Cruz Biotechnology (SC-372 and SC-203, respectively). 
Electrophoretic mobility shift assays (EMSA) were performed by using the Gel Shift Assay System (Promega) according to the manufacturer's instruction. Nuclear extracts were prepared from untreated control cells, and cells treated with TNF $\alpha$ alone or together with $5 \mu \mathrm{M}$ $\mathrm{H}_{2} \mathrm{O}_{2}$. The NF- $\kappa \mathrm{B}$ consensus oligonucleotide (AGTTGAGGGGACTTTCCCAGGC) was endlabeled using $\left[\gamma_{-}{ }^{32} \mathrm{P}\right] \mathrm{ATP}$. The reaction mixture contained $4 \mu \mathrm{l} 5 \times$ gel shift binding buffer, $1 \mu \mathrm{l}$ of ${ }^{32} \mathrm{P}$ labeled NF- $\kappa \mathrm{B}(15,000 \mathrm{cpm})$ consensus oligonucleotide probe, $10 \mu \mathrm{g}$ of nuclear extract in a total volume of $20 \mu \mathrm{l}$. The reaction was incubated at room temperature for $20 \mathrm{~min}$. After incubation, the samples were loaded on $4 \%$ nondenaturing polyacrylamide gel and were electrophoresed at 150 volts for $3 \mathrm{hr}$. The gel was dried and autoradiograph was developed. After the autoradiography, the bands were cut out, counted, and the specific radioactivity associated with each band was calculated.

Statistical analysis was carried out by oneway ANOVA followed by Dunnett's test and by one-way ANOVA for repeated measures followed by Turkey test using SigmaStat Software ( $p$ values $<.05$ were considered statistically significant). All graph data are presented as Mean $\pm \mathrm{SD}$.

\section{Results}

TNF $\alpha$ and $\mathrm{H}_{2} \mathrm{O}_{2}$ Have a Synergistic Effect on Induction of Apoptosis

It has previously been shown that human $\mathrm{TNF} \alpha$ was not cytotoxic for cultured HBEC at doses of $15 \mathrm{ng} / \mathrm{ml}(250 \mathrm{EU} / \mathrm{ml})$, although this dose caused cell activation (34). Similarly in RBEC, while causing activation of ICAM- 1 adhesion ligand, TNF $\alpha$ exhibited no cytotoxicity at the dose of $20 \mathrm{ng} / \mathrm{ml}$ (24). Thus, these doses of $\mathrm{TNF} \alpha$ were adopted for current investigation. To test the hypothesis that the combination of TNF $\alpha$ and ROS will have a synergistic effect on cell viability, HBEC were treated with a combination of $\mathrm{TNF} \alpha(15 \mathrm{ng} / \mathrm{ml})$ and $\mathrm{H}_{2} \mathrm{O}_{2}(100 \mu \mathrm{M})$ for $4 \mathrm{hr}$. Cell viability was monitored under phase contrast field. When added separately, TNF $\alpha$ and $\mathrm{H}_{2} \mathrm{O}_{2}$ caused no morphological changes (Fig. 1B and C) when compared to control cultures (Fig. 1A), addition of both agonists resulted in cell death (Fig. 1D).

To further investigate the effect of $\mathrm{H}_{2} \mathrm{O}_{2}$ cells were treated with lower doses of $\mathrm{H}_{2} \mathrm{O}_{2}(5$ and
$10 \mu \mathrm{M}$ for HBEC and RBEC, respectively) in the presence of TNF $\alpha$ for $24 \mathrm{hr}$ and the number of apoptotic cells was quantitated with TUNEL assay. The results are presented in Figure $2 \mathrm{~A}$ (HBEC) and Figure 2B (RBEC). The top panel of each figure presents photomicrographs of endothelial cultures after treatment. The bottom pannel presents binary images of corresponding photomicrographs with highlighted TUNEL-positive areas. TNF $\alpha$ alone for $24 \mathrm{hr}$ remained healthy, with few TUNEL-positive cells (photomicrographs a and binary images $\mathrm{d}$ in both Fig. 2A and B). Similarly, $\mathrm{H}_{2} \mathrm{O}_{2}$ alone had no effect on cell viability (photomicrograph $\mathrm{b}$ and binary image $\mathrm{e}$ in both Fig. 2A and $\mathrm{B}$ ). Addition of $\mathrm{H}_{2} \mathrm{O}_{2}$ together with $\mathrm{TNF} \alpha$ resulted in the appearance of many TUNELpositive cells exhibiting apoptotic morphology (shrinking of the cytoplasm, chromatin condensation, pyknosis) (photomicrograph $\mathrm{c}$ and binary image $f$ in both Fig. 2A and B). Results of quantitation of percentage of TUNELpositive nuclei with ScionImage program are presented in Table 1. It demonstrates that endothelial cell cultures treated with both TNF $\alpha$ and $\mathrm{H}_{2} \mathrm{O}_{2}$ exhibited two times more apoptotic cells than control cultures or cultures treated with TNF $\alpha$ or $\mathrm{H}_{2} \mathrm{O}_{2}$ alone $(p<.05)$.

To study the synergistic effect of TNF $\alpha$ and $\mathrm{H}_{2} \mathrm{O}_{2}$ in more detail, we have used the Hoechst assay, which is apparently more sensitive indicator of DNA fragmentation (32). Besides endothelial cells, cortical astrocytes also have been studied. Cells were treated with TNF $\alpha$ in combination with various doses $(0-10 \mu \mathrm{M})$ of $\mathrm{H}_{2} \mathrm{O}_{2}$. Because DNA fragmentation occurs early in the course of apoptosis, the cultures were evaluated 15-16 hr after addition of TNF $\alpha$ and of $\mathrm{H}_{2} \mathrm{O}_{2}$. Lower doses of $\mathrm{H}_{2} \mathrm{O}_{2}(1-3 \mu \mathrm{M})$ were required to initiate DNA fragmentation measured in this assay compared to TUNEL assay as cells need a longer time to undergo fullblown apoptosis. Rat brain capillary endothelial cells were more sensitive to $\mathrm{TNF} \alpha / \mathrm{H}_{2} \mathrm{O}_{2}$ treatment than astrocytes. Addition of as little as $0.3-1 \mu \mathrm{M}$ of $\mathrm{H}_{2} \mathrm{O}_{2}$ together with $10 \mathrm{ng} / \mathrm{ml}$ $\mathrm{TNF} \alpha$ resulted in apoptosis of the majority of the RBEC (Fig. 3A), whereas 1-3 $\mu \mathrm{M} \mathrm{H}_{2} \mathrm{O}_{2}$ caused the same effect in astrocytes (Fig. 3B).

\section{$\mathrm{H}_{2} \mathrm{O}_{2}$ Inhibits TNF $\alpha$-induced Activation of NF- $\kappa B$}

Transcription of many TNF $\alpha$-activated genes depends on the transcription factor, NF- $\kappa \mathrm{B}$. However, NF- $\kappa$ B activation could be altered by 

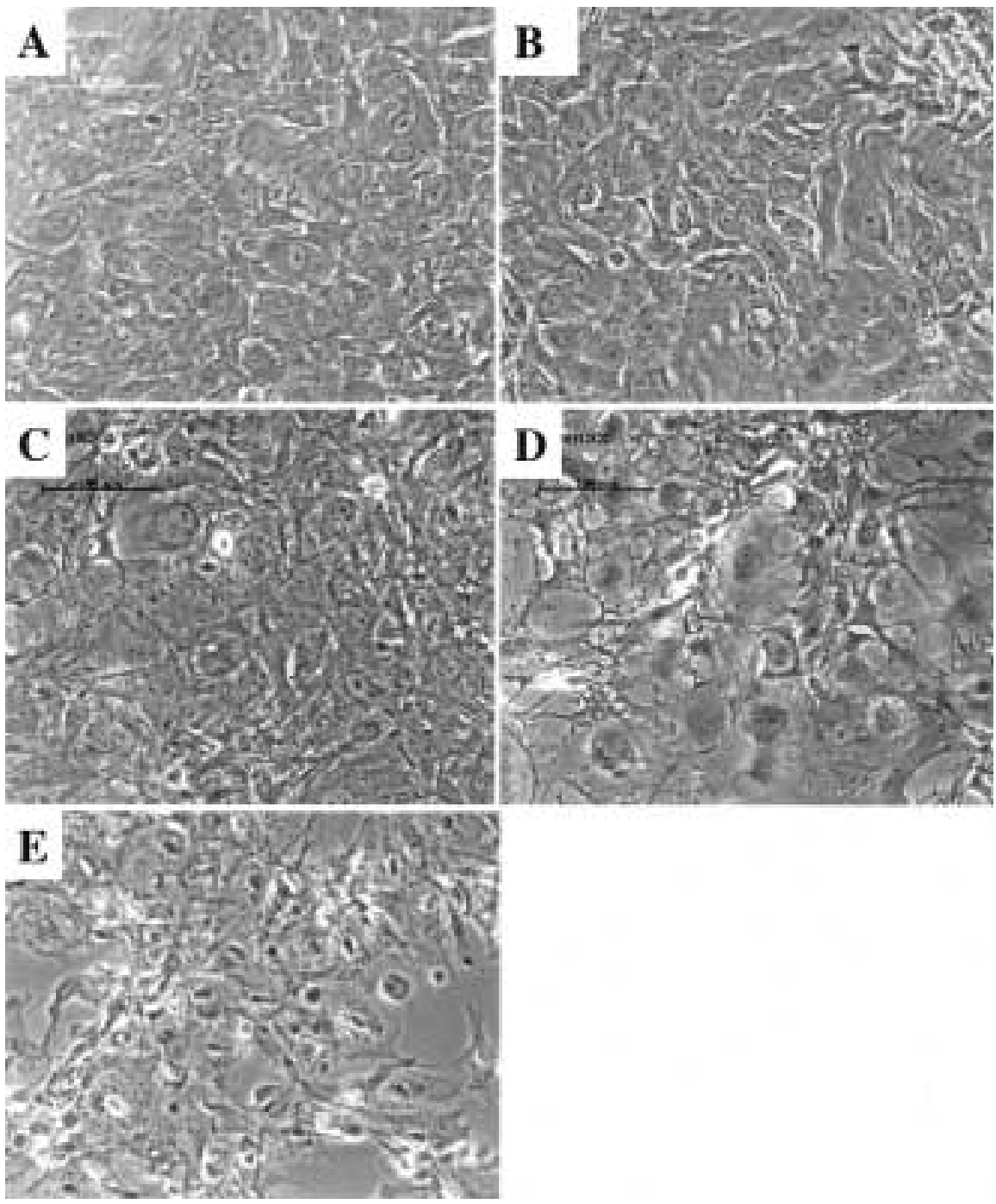

Fig. 1. Synergistic effect of tumor necrosis factor alpha and $\mathrm{H}_{2} \mathrm{O}_{2}$ on induction of apoptosis. Human brain capillary endothelial cells were treated with a combination of $\mathrm{TNF} \alpha$ (15 ng/ml) and $\mathrm{H}_{2} \mathrm{O}_{2}(100 \mu \mathrm{M})$ for $24 \mathrm{hr}$. Cell

ROS and antioxidants. Thus, we hypothesized that $\mathrm{H}_{2} \mathrm{O}_{2}$ might interfere with TNF $\alpha$-induced NF $-\kappa \mathrm{B}$ activation precipitating cell death. To test this hypothesis, we have studied NF- $\kappa$ B activation in RBEC. Cells were treated with $20 \mathrm{ng} / \mathrm{ml} \mathrm{TNF} \alpha$ for various times, and then $\mathrm{I} \kappa \mathrm{B}$ and p65 levels were determined in cytoplasmic and nuclear extracts, respectively, by means of Western blotting and ScionImage analysis as described in Materials and Methods. The results of these experiments are presented in Figure $4 \mathrm{~A}-\mathrm{D}$. $\mathrm{I} \kappa \mathrm{B}$ degradation in cytoplasm began as early as 10 min after $\mathrm{TNF} \alpha$ addition; at $20 \mathrm{~min} \mathrm{I} \kappa \mathrm{B}$ levels in cytoplasm dropped to $22.5 \pm 6.2 \% \quad($ mean $\pm \mathrm{SD} ; n=4)$ of baseline viability was monitored under phase contrast field (objective $20 \times$ ). (A) Untreated cells; (B) TNF $\alpha$ alone; (C) $\mathrm{H}_{2} \mathrm{O}_{2}$ alone; (D) TNF $\alpha$ and $\mathrm{H}_{2} \mathrm{O}_{2}$ together; (E) NF- $\kappa$ B inhibitor BAY11-7082.

levels and remained that low for another 10 min. At $1 \mathrm{hr}$ after $\mathrm{TNF} \alpha$ addition, I $\kappa \mathrm{B}$ levels returned to about $70 \%$ of control values (Fig. $4 \mathrm{~A}$ and $\mathrm{B}$ ). Addition of $2 \mu \mathrm{M} \mathrm{H}_{2} \mathrm{O}_{2}$ had no significant effect on $\mathrm{I} \kappa \mathrm{B}$ degradation. I $\kappa \mathrm{B}$ degradation had almost identical kinetics in the absence or presence of $\mathrm{H}_{2} \mathrm{O}_{2}$. Addition of $2 \mu \mathrm{M}$ $\mathrm{H}_{2} \mathrm{O}_{2}$ alone without TNF $\alpha$ caused no degradation of $\mathrm{I} \kappa \mathrm{B}$. At $20 \mathrm{~min}, \mathrm{I} \kappa \mathrm{B}$ levels were $109.8 \pm$ $0.05 \%$ control (mean $\pm \mathrm{SD} ; n=2)$. There was a constitutive p65 presence in the nucleus of brain cells. In all experiments $(n=5)$, antibody identified two bands. We suggest that one of the bands is a phosphorylated form of p65. Accumulation of p65 subunit in the nucleus 

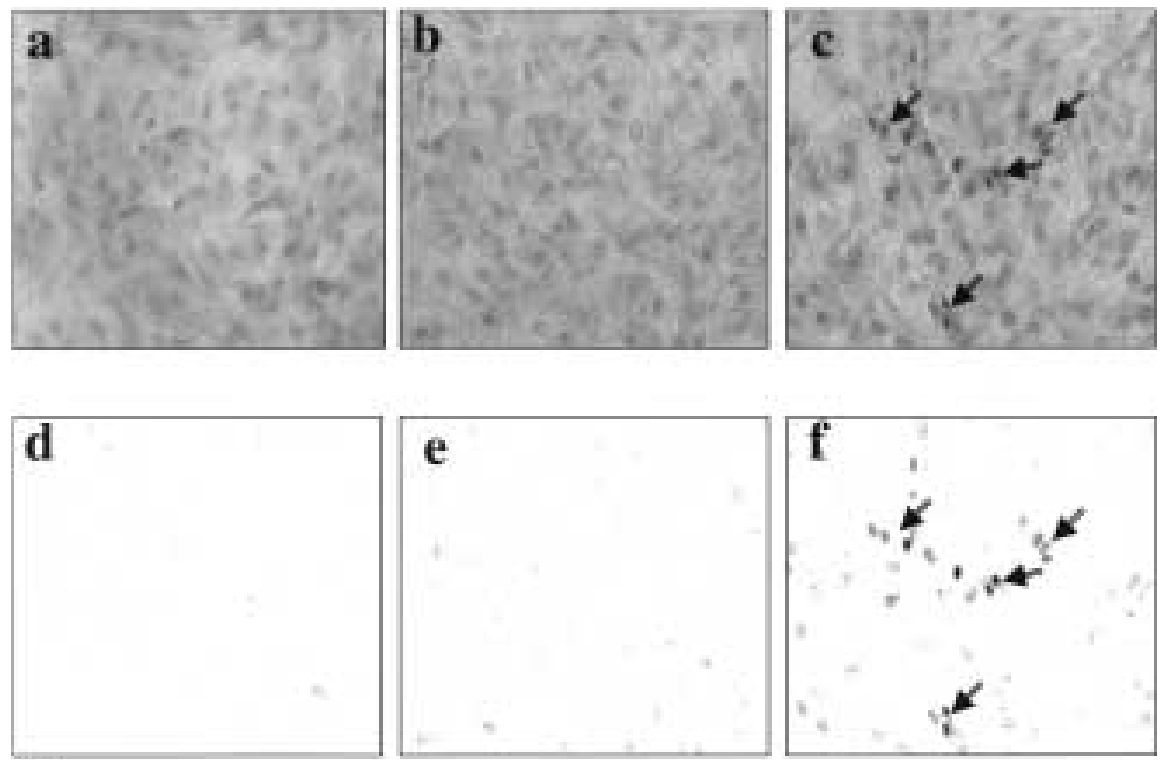

A)
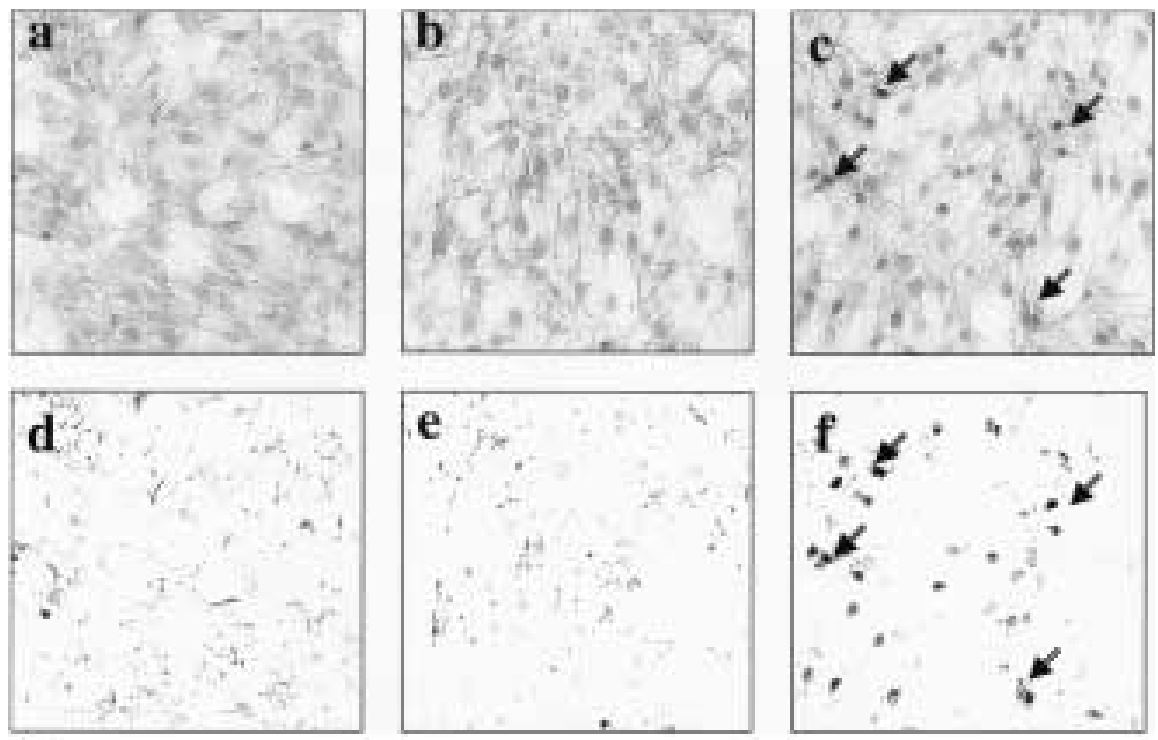

B)

Fig. 2. Synergistic effect of tumor necrosis factor alpha (TNF $\alpha$ ) and $\mathrm{H}_{2} \mathrm{O}_{2}$ on the number of TUNEL-positive cells. (A) Human brain capillary endothelial cells, and (B) rat brain capillary endothelial cells were treated with either TNF $\alpha$ (photomicrographs a and d) or $\mathrm{H}_{2} \mathrm{O}_{2}$ (photomicrographs $b$ and e) or with both agonists (photomicrographs c and f) for $24 \mathrm{hr}$ and apoptotic nuclei were visualized with TUNEL assay as described in

paralleled degradation of $\mathrm{I} \kappa \mathrm{B}$ in the cytoplasm and peaked at $20 \mathrm{~min}$ after $\mathrm{TNF} \alpha$ addition $(153.0 \pm 25.8 \%$ baseline; mean $\pm \mathrm{SD} ; n=5)$ (Fig. 4C and D). Addition of $2 \mu \mathrm{M} \mathrm{H}_{2} \mathrm{O}_{2}$ to the cells simultaneously with $\mathrm{TNF} \alpha$ completely inhibited p65 translocation to the nucleus:
Materials and Methods. Photomicrographs are representatives of 15 images captured for each condition. The top row of panels (A) and (B) (photomicrographs $\mathrm{a}, \mathrm{b}$, and $\mathrm{c}$ ) are phase-contrast images, the bottom row of panels (A) and (B) (photomicrographs $\mathrm{d}, \mathrm{e}$, and $\mathrm{f}$ ) are corresponding binary images. Apoptotic nuclei are indicated with arrows.

measured p65 levels at 20 min were $109.5 \pm$ $21.1 \%$ baseline $(p<0.05$ vs. TNF $\alpha)$. Addition of $2 \mu \mathrm{M} \mathrm{H}_{2} \mathrm{O}_{2}$ alone without TNF $\alpha$ resulted in no significant increase of p65 levels in the nucleus. At $20 \mathrm{~min}, \mathrm{p} 65$ levels were $110.6 \pm 5.7 \%$ control (mean $\pm \mathrm{SD} ; n=3$ ). 
Table 1. Synergistic effect of TNF $\alpha$ and $\mathrm{H}_{2} \mathrm{O}_{2}$ on induction of apoptosis and percentage of TUNEL-positive nuclei

\begin{tabular}{lllrrr}
\hline & Treatment & \multicolumn{1}{c}{$\begin{array}{c}\text { TNF } \alpha \\
\mathbf{H}_{2} \mathbf{O}_{2}\end{array}$} & \multicolumn{1}{c}{$\begin{array}{c}\text { TNF } \alpha \\
\text { none }\end{array}$} & $\begin{array}{r}\text { none } \\
\mathbf{H}_{2} \mathbf{O}_{2}\end{array}$ & $\begin{array}{r}\text { none } \\
\text { none }\end{array}$ \\
\hline RBEC 1 & \% apoptotic cells & $27.7 \pm 8.0^{*}$ & $14.8 \pm 11.9$ & $15.8 \pm 9.4$ & $14.8 \pm 8.8$ \\
RBEC 2 & \% apoptotic cells & $31.3 \pm 11.8^{*}$ & $17.4 \pm 6.1$ & $12.7 \pm 4.7$ & $14.8 \pm 6.6$ \\
HBEC & \% apoptotic cells & $30.8 \pm 9.1^{*}$ & $7.2 \pm 3.3$ & $4.2 \pm 2.5$ & $2.6 \pm 1.5$ \\
\hline
\end{tabular}

Rat brain capillary endothelial cells and human brain capillary endothelial cells were treated with either TNF $\alpha$ or $\mathrm{H}_{2} \mathrm{O}_{2}$ or with both agonists for $24 \mathrm{hr}$ and apoptotic nuclei were stained with TUNEL assay and quantitated by means of ScionImage software as described in Materials and Methods. Each data point represents percentage of TUNEL-positive nuclei per a microscopic field (mean \pm SD of 15 microscopic fields). The summaries of the results of three separate experiments (two in RBEC and one in HBEC) are presented. Statistical comparison between synergistic treatment with TNF $\alpha$ and $\mathrm{H}_{2} \mathrm{O}_{2}$ and separate treatments was performed by means of one-way ANOVA followed by Dunnett's test. Data marked with * statistically differ from all other groups ( $p$ values $<.05)$.

The results of Western blots were confirmed with electrophoretic mobility shift assay. Nuclear extracts of untreated HBEC cells had little DNA-binding activity. Drastic upregulation of DNA-binding activity was caused by TNF $\alpha$ alone. However, addition of $5 \mu \mathrm{M}$ $\mathrm{H}_{2} \mathrm{O}_{2}$ together with TNF $\alpha$ inhibited DNA binding by $40 \%$ (Fig. $4 \mathrm{E}$ and $\mathrm{F}$ ).

\section{$\mathrm{H}_{2} \mathrm{O}_{2}$ Inhibits Nuclear Transport of $p 65$ Subunit of NF- $\kappa B$}

Two subunits comprise NF- $\kappa \mathrm{B}$, which belong to Rel family of proteins. The most frequently found NF- $\kappa$ B heterodimer is $\mathrm{p} 65 / \mathrm{p} 50$. Interaction of the subunits with the inhibitor of NF$\kappa \mathrm{B}(\mathrm{I} \kappa \mathrm{B})$ masks the nuclear translocation sequence of NF- $\kappa \mathrm{B}$ and retains the heterodimer in cytoplasm. Upon activation with TNF $\alpha$ and other agonists, $\mathrm{I} \kappa \mathrm{B}$ gets phosphorylated by a specific kinase, ubiquitinated, and subsequently degraded by proteasome peptidases (35). Removal of $\mathrm{I} \kappa \mathrm{B}$-alpha uncovers the nuclear localization signals of subunits of NF- $\kappa \mathrm{B}$, allowing the complex to enter the nucleus, bind to DNA, and affect gene expression. The results of Western blots presented in Figure 4 demonstrate that, although TNF $\alpha$-induced I $\kappa \mathrm{B}$ degradation was not affected by $\mathrm{H}_{2} \mathrm{O}_{2}$ (Fig. 4A and $\mathrm{B})$, and should result in release of a free p65/p55 heterodimer in cytoplasm, the p65 subunit did not appear in the nucleus (Fig. 4C and D), suggesting that transport of p65 from cytoplasm to the nucleus was compromised. To confirm this assumption, RBEC were treated with $20 \mathrm{ng} / \mathrm{ml}$ TNF- $\alpha$ or with $5 \mu \mathrm{M} \mathrm{H}_{2} \mathrm{O}_{2}$ or with both agonists for $30 \mathrm{~min}$ and then fixed and immunostained with anti-p65 antibodies. In control, untreated cells (Fig. 5A) and in the cells treated with $\mathrm{H}_{2} \mathrm{O}_{2}$ alone (Fig. 5B), immunofluorescence was spread over cytoplasm and was not found in the nucleus. Treatment with TNF $\alpha$ caused redistribution of fluorescence with maximal signal coming from the nucleus (arrows) (Fig. 5C). Although there was some background fluorescence in the nuclei of control and $\mathrm{H}_{2} \mathrm{O}_{2}$-treated cells (Fig. 5A and B), it had an appearance of small granules, whereas in TNF-treated cells (Fig. 5C), the whole nucleus was highlighted. Addition of $\mathrm{TNF} \alpha$ together with $\mathrm{H}_{2} \mathrm{O}_{2}$ resulted in no accumulation of fluorescence in the nucleus, and most of the bright spots are localized in perinuclear forming a dense circle (Fig. 5D). This pattern was somewhat different from that of control cells, and was consistently observed in all captured images. Similar results were obtained in HBEC using an antibody directed against an activated form of p65 (data not shown).

\section{Inhibitor of NF- $\kappa B$ Causes Apoptosis}

To investigate the role NF- $\kappa$ B in survival of endothelial cells, HBEC were incubated with different doses $(1-10 \mu \mathrm{M})$ of the NF- $\kappa$ B inhibitor BAY 11-7082 (E-3-[4-methylphenylsulfonyl]2-propenenitrile) (Biomol Research Laboratories, Inc. Plymouth Meeting, PA, USA). Cell morphology was analyzed $4 \mathrm{hr}$ later with a Zeiss Axiovert 100 light microscope $(20 \times$ objective) and the images were captured as described in Materials and Methods. At a dose as low as $1 \mu \mathrm{M}$, the inhibitor caused apoptosis (Fig. 1E). 


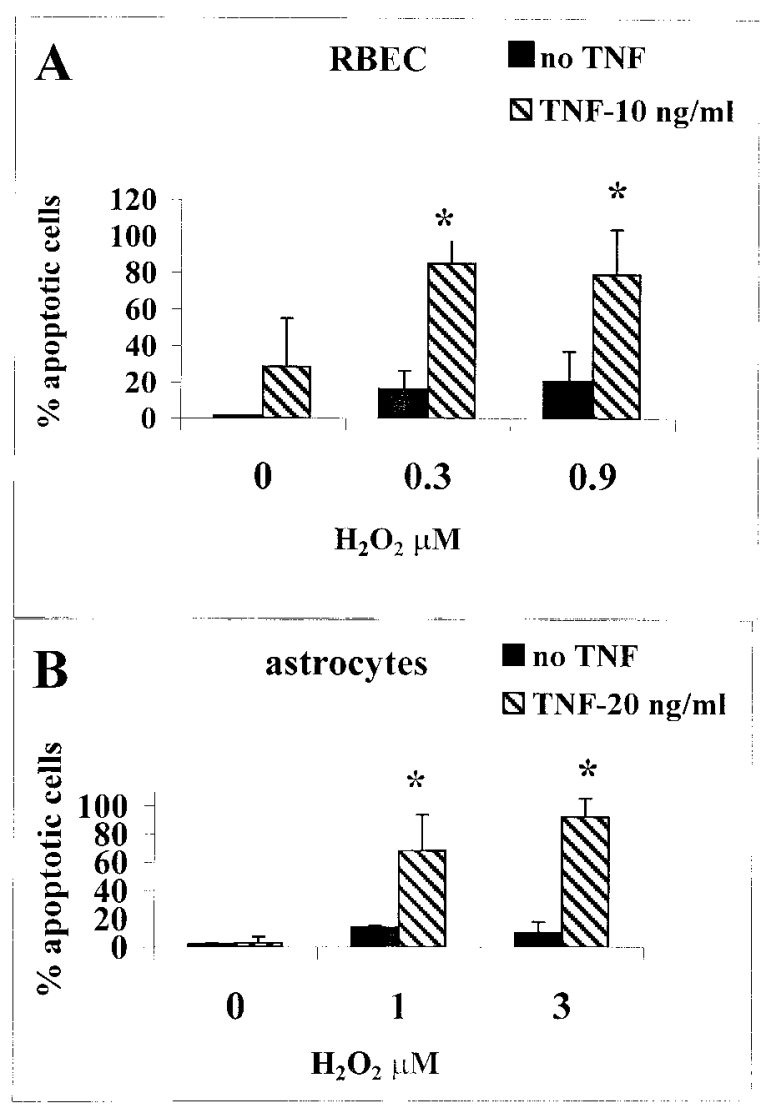

Fig. 3. Synergistic effect of tumor necrosis factor alpha (TNF $\alpha$ ) and $\mathrm{H}_{2} \mathrm{O}_{2}$ on induction of DNA fragmentation. (A) Rat brain capillary endothelial cells, and (B) astrocytes were grown to confluency in 96 well plates. Cells were incubated with various doses of $\mathrm{H}_{2} \mathrm{O}_{2}$ in the presence or absence of TNF $\alpha$ for $16 \mathrm{hr}$. At the end of the incubation, cells were stained with Hoechst 33342 and decrease of fluorescence dependent on DNA fragmentation was quantitated by a fluorescent plate reader as described in Materials and Methods. Each measurement was done in six wells and averaged. The bar graphs represent mean \pm SD of three experiments performed in different cell cultures. "*" Marks significant difference between the treatments with and without TNF $(p<.05)$.

\section{Discussion}

Ischemic and traumatic brain injury are accompanied by oxidative stress (36-38) and release of proinflammatory cytokines, TNF $\alpha$ and IL- $1 \beta$ $(8,39)$. Although these pathogenic reactions have been extensively studied, there is no consensus of opinion on mechanisms of their action and interaction. Oxidants have been shown to stimulate signaling pathways usually triggered by growth factors (activation of protein tyrosine kinases and phosphatases, PKC and mitogen-activated kinases, phospholipases $\mathrm{C} \gamma$ and $\mathrm{A}_{2}$ and $\mathrm{Ca}^{2+}(40)$. Similarly, it has been thought that TNF $\alpha$ also induces release of ROS (mainly $\mathrm{H}_{2} \mathrm{O}_{2}$ ) in mitochondria (41) and through NADPH oxidase (42) and then ROS act as messengers in TNF $\alpha$ signaling pathways leading to NF- $\kappa \mathrm{B}$-dependent transcription of pro-inflammatory genes (43-45) and to cell death (46). However, although $\mathrm{H}_{2} \mathrm{O}_{2}$ activates $\mathrm{NF}-\kappa \mathrm{B}$ in some cell types, it fails to do so in human endothelial cells $(47,48)$, in lymphoblastoid (49), and in monocytic cell lines (50). Moreover, since the first observations of the anti-apoptotic effects of NF- $\kappa$ B have been published (51-53), the role of NF- $\kappa$ B in cell death has been revised. Much evidence has emerged that demonstrates that NF- $\kappa \mathrm{B}$ activates transcription of protective genes in different types of cells (54), including brain cells $(55,56)$ rather than causing cell death. Furthermore, inhibition of NF- $\kappa$ B sensitizes neurons to cytotoxic effects of amyloid beta (57), and activation of NF- $\kappa$ B promotes neuronal survival $(58,59)$. These observations suggest an alternative mechanism for interaction between $\mathrm{TNF} \alpha$ and ROS in induction of cell death.

In this work, we present evidence supporting the hypothesis that ROS cooperate with TNF $\alpha$ and induce cell death via inhibition of $\mathrm{NF}-\kappa \mathrm{B}$. For the first time, we demonstrate that low doses of $\mathrm{H}_{2} \mathrm{O}_{2}$, which are not capable of causing cell death on their own, synergize with $\mathrm{TNF} \alpha$ and unmask TNF $\alpha$ cytotoxicity in cultured brain endothelial cells and astrocytes. This conclusion is based on the results of morphological studies and TUNEL staining for apoptotic cells, as well as on quantitation of DNA fragmentation with Hoechst 33342, which is a cell-permeable DNA-binding fluorescent dye. Hoechst fluorescence is inversely proportional to the degree of DNA fragmentation (60). A synergistic effect of $\mathrm{TNF} \alpha$ and $\mathrm{H}_{2} \mathrm{O}_{2}$ was demonstrated in both assays. When treated with $\mathrm{TNF} \alpha$ alone for $24 \mathrm{hr}$, HBEC, RBEC, and astrocytes showed a low rate of apoptosis, most probably caused by culture conditions. However, addition of low doses of $\mathrm{H}_{2} \mathrm{O}_{2}$, together with $\mathrm{TNF} \alpha$, results in early DNA fragmentation followed by appearance of TUNEL-positive apoptotic cells. Interestingly, in our preliminary experiments, we used a cell-impermeable fluorescent dye, ethidium homodimer, to assess cell viability. Healthy cells exclude ethidium, but those with a damaged plasma membrane, generally necrotic 

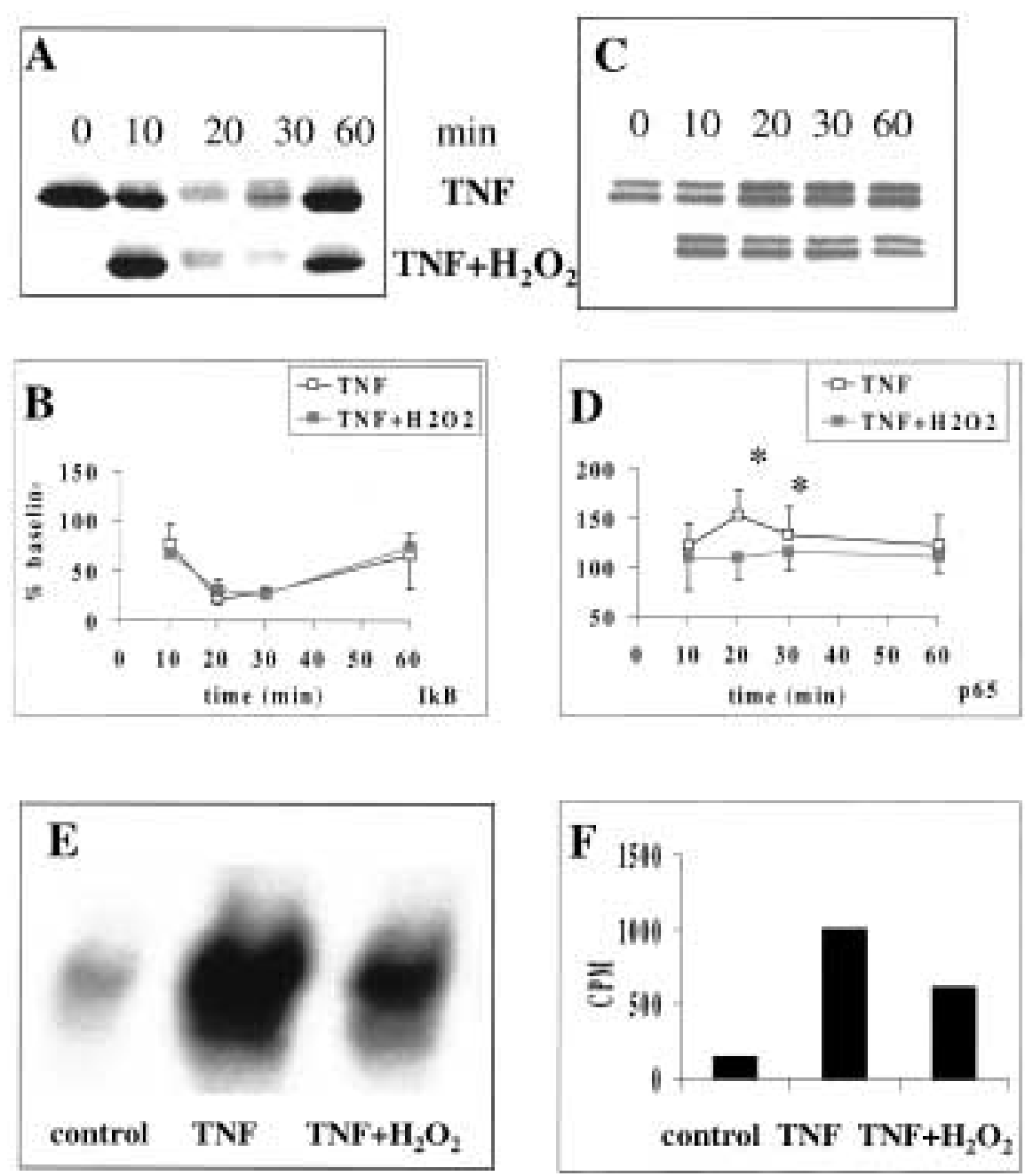

Fig. 4. $\mathrm{H}_{2} \mathrm{O}_{2}$ inhibits tumor necrosis factor alpha (TNF $\alpha)$-induced activation of NF- $\kappa$ B. Rat brain capillary endothelial cells were activated with TNF $\alpha$ in the absence or presence of 2-5 $\mu \mathrm{M}$ $\mathrm{H}_{2} \mathrm{O}_{2}$ for indicated times $(0-60 \mathrm{~min})$. At the end of each incubation, cytoplasmic and nuclear extracts were prepared as described in Materials and Methods. Extracts were subjected to SDS-PAGE and immunobloted with antibodies directed either against I $\kappa$ B (cytocolic extracts, panels A and B) or against p65 subunit of NF- $\kappa \mathrm{B}$ (nuclear extracts, panels $C$ and D). (A) and (B) Representative results of Western blots. (B) and (D) Results of densitometry

cells, accumulate the dye and become highly fluorescent. In these experiments, doses of $\mathrm{H}_{2} \mathrm{O}_{2}$ required to produce membrane permeability (ethidium assay) were higher (10-20 $\mu \mathrm{M}$ depending on the culture; data not shown) than those needed to cause DNA fragmentation (1$5 \mu \mathrm{M})$ in the presence of the same dose of TNF $\alpha$. This dichotomy fits the definition of necrosis and apoptosis well. Necrosis is an uncontrolled degenerative phenomenon invari-

analysis of protein bands. Each data point represents mean $\pm \mathrm{SD}$ of four to five experiments. “*” Marks significant difference between the treatments with and without $\mathrm{H}_{2} \mathrm{O}_{2}$ (ANOVA for repetitive measurements; $p<.05$ ). (E) and (F) Representative of electrophoretic mobility shift assays (EMSA) $(n=3)$. Nuclear extracts were prepared from untreated cells (control), or cells treated with TNF $\alpha$ alone (TNF) or together with $5 \mu \mathrm{M} \mathrm{H}_{2} \mathrm{O}_{2}$ (TNF $+\mathrm{H}_{2} \mathrm{O}_{2}$ ) and EMSA was performed as described in Materials and Methods. (F) The specific radioactivity associated with each band is presented.

ably caused by noxious stimuli and is the result of irreversible failure of membrane function. In contrast, apoptosis is a death process that involves a series of well-organized events that require active cell participation, and is primarily caused by physiological stimuli. Previous observations showing that low doses of ROS induce apoptosis, whereas necrosis occurs in cells exposed to higher doses of ROS (61-63) are in accordance with our findings. 

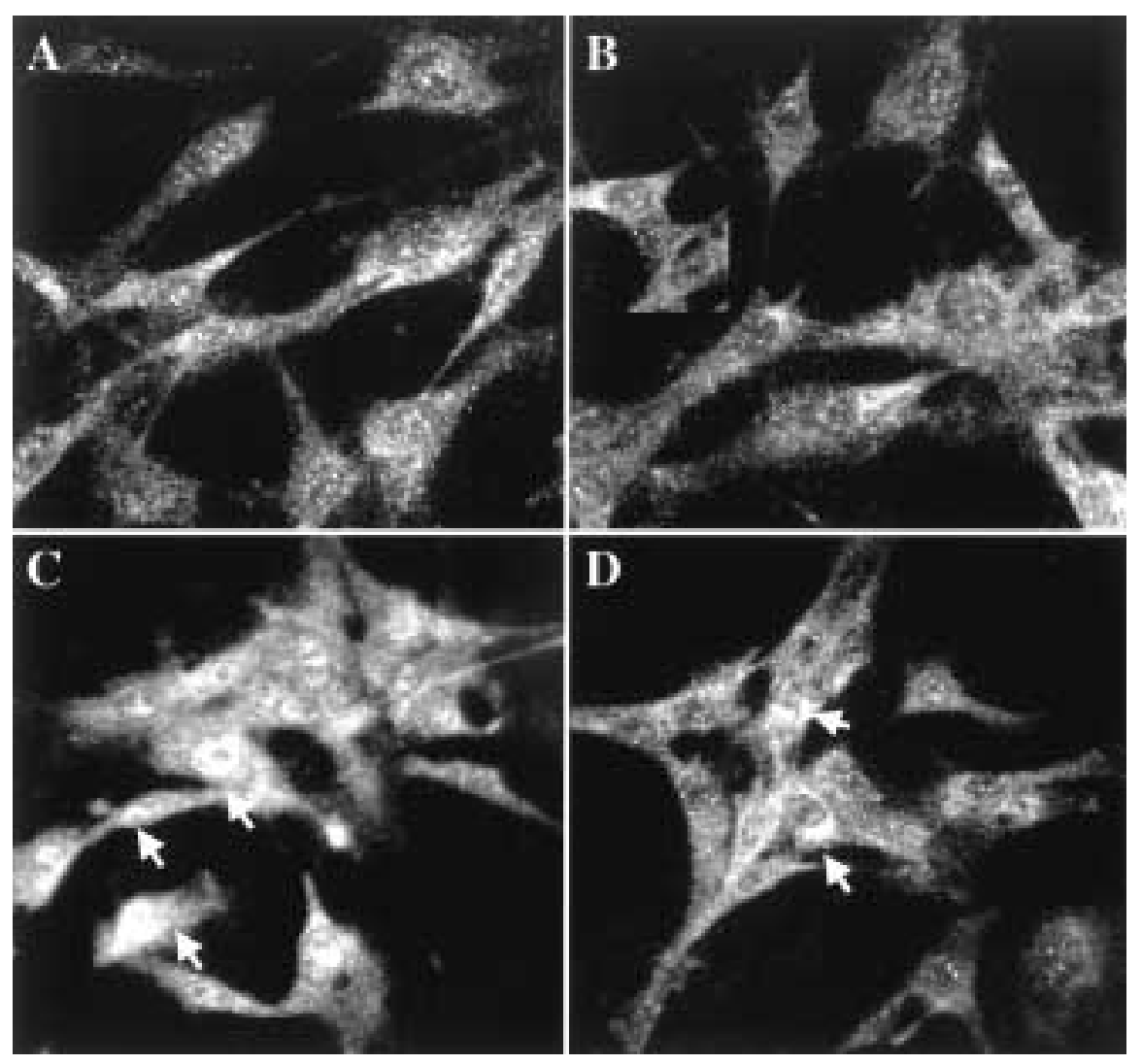

Fig. 5. $\mathrm{H}_{2} \mathrm{O}_{2}$ inhibits tumor necrosis factor alpha $(\mathrm{TNF} \alpha)$-induced nuclear translocation of NF- $\boldsymbol{K} B$. (A) rat brain capillary endothelial cells untreated and those treated with (B) $\mathrm{H}_{2} \mathrm{O}_{2}$ or with (C) TNF $\alpha$ alone or with (D) both agonists for $30 \mathrm{~min}$, were fixed and

Chemical reactivity and redox potentials of ROS range from reducing to oxidizing: superoxide anion radical can be reduced to $\mathrm{H}_{2} \mathrm{O}_{2}$ by superoxide dismutase, the latter can be further reduced by the Fenton reaction with iron to the hydroxyl radical, which is capable of oxidizing nucleic acids, lipids, and proteins. Employment of specific scavengers for different types of ROS has demonstrated that some but not all of these species activate NF- $\kappa$ B (64). It has been demonstrated that all the steps of $\mathrm{NF}-\kappa \mathrm{B}$ activation ( $\mathrm{K} \kappa \mathrm{B}$ phosphorylation and degradation, p65/p55 nuclear translocation, and DNA binding) are redox-sensitive (65-68). Our data suggests that low doses of ROS have no effect on the steps involved in degradation of I $\kappa \mathrm{B}$ but alter TNF $\alpha$-induced nuclear translocation of at least the p65 subunit of NF- $\kappa$ B. Quantitation of I $\kappa$ B levels in TNF $\alpha$-treated RBEC demonstrated almost complete disappearance of the inhibitor from the cytoplasm at $20 \mathrm{~min}$; $\mathrm{I} \kappa \mathrm{B}$ gene itself has an NF- $\kappa \mathrm{B}$ immunostained with anti-p65 antibody as described in Materials and Methods. Arrows denote accumulation of immunofluorescence in the nucleus in TNF $\alpha$-treated cells (C) and in perinuclear area in cells treated with TNF $\alpha$ and $\mathrm{H}_{2} \mathrm{O}_{2}$ (D).

binding site, so it is quickly resynthesized (69). By $60 \mathrm{~min} \sim 60 \%$ of $\mathrm{I} \kappa \mathrm{B}$ protein could be detected in TNF $\alpha$-stimulated RBEC. These kinetics of $\mathrm{I} \kappa \mathrm{B}$ degradation and resynthesis did not change in the presence of $\mathrm{H}_{2} \mathrm{O}_{2}$, which means that free NF- $\kappa \mathrm{B}$ heterodimer is released in the cytoplasm and should be transported to the nucleus. However, we were unable to detect increased levels of p65 in the nucleus in the cells treated with TNF $\alpha$ and $\mathrm{H}_{2} \mathrm{O}_{2}$, although TNF $\alpha$ alone triggered a 1.5-fold increase of p65 levels in the nucleus. This result was confirmed by gel-shift assay and immunostaining experiments, which demonstrated that TNF $\alpha$ failed to induce translocation of the p65 subunit to the nucleus in the presence of $\mathrm{H}_{2} \mathrm{O}_{2}$ and instead caused accumulation of the p65 in the perinuclear area. Similarly, high doses of amyloid beta peptide, known to elicit production of ROS, have been shown to inhibit nuclear transport of p65 $(57,70)$. 
Our data strongly suggest that $\mathrm{H}_{2} \mathrm{O}_{2}$ precipitates TNF $\alpha$ cytotoxicity by inhibiting transcription of the NF- $\kappa \mathrm{B}$-dependent protective genes. However, other mechanisms are not excluded by these studies. Thus treatment of the cells with low concentrations of $\mathrm{H}_{2} \mathrm{O}_{2}$ induces activation of caspases, cysteine proteases that constitute part of apoptotic machinery (63). In addition, TNF $\alpha$-induced activation of sphingomyelinase and consequent release of ceramide, a phospholipid messenger implicated in apoptosis, could be prevented by antioxidants and stimulated by $\mathrm{H}_{2} \mathrm{O}_{2}$ in astrocytes (71). In our studies, we have shown that physiological doses of C-2 ceramide failed to induce apoptosis in cultured astrocytes and RBEC but higher doses were apoptotic (33). Another possibility is that ROS by interfering with ceramide metabolism allow higher intracellular levels of ceramide and cause cell death.

There is evidence that NF- $\kappa \mathrm{B}$ is constitutively expressed in neuronal cells and mediates their resistance to different types of stress $(55,72,73)$, and that neurons from mice lacking the $\mathrm{p} 50$ subunit of NF- $\kappa \mathrm{B}$ are more vulnerable to excitotoxic stress (74). Our Western blot data demonstrate constitutive presence of p65 in the nucleus of brain microvascular cells and inhibition of this NF- $\kappa$ B activity in HBEC cultures by low doses of NF- $\kappa$ B inhibitor BAY11-7082 resulted in rapid apoptosis. Our results are consistent with findings of Taglialatela et al. (76). However, observations in animals are not consistent. Thus suppression of NF- $\kappa \mathrm{B}$ activity in brain by a specific inhibitor resulted in DNA fragmentation (76), but TNF $\alpha$ receptor knockout mice, which exhibited delayed up-regulation of NF- $\kappa$ B after traumatic brain injury, had a larger average lesion volume and blood brain barrier breach than wild-type animals (77). Also, p50 knockout mice tolerated ischemic injury better than wild-type animals (74). NF- $\kappa \mathrm{B}$ activity was shown to increase after brain trauma (79) and in the model of transient focal ischemia $72 \mathrm{hr}$ after reperfusion. (78). In the latter model and also in the model of intracerebral hemorrhage, activated NF- $\kappa$ B colocalized with apoptotic cells $(78,80)$. However, in a rat model of permanent MCAO, activated NF- $\kappa \mathrm{B}$ immunoreactivity decreased from basal levels already at $2 \mathrm{hr}$ after onset of ischemia and remained undetectable up to 5 days (75). Interestingly, antioxidant-dependent protection against transient focal ischemia was associated with inhibition of NF- $\kappa$ B (81) but in global ischemia antioxidants inhibited only persistent NF- $\kappa$ B activity in hyppocampal CAl neurons, whereas transient activation of NF- $\kappa$ B seemed to be protective (82). Overexpression of Mn-SOD in human breast cancer MCF-7 cells completely abolished TNFmediated NF- $\kappa$ B activation, and caused apoptosis (83). These contradictions call for more detailed studies of NF-B activation in vivo. Time, localization, and variations in NF- $\kappa$ B heterodimer composition should be taken into account.

In conclusion, the data presented here suggests a new pharmacological approach to the treatment of brain injury. Instead of targeting TNF $\alpha$ and ROS separately, one might want to interfere with the cross-talk mechanisms of these two pathogenic pathways that modulate NF- $\kappa \mathrm{B}$ dependent anti-apoptotic signaling.

\section{Acknowledgments}

The authors thank Joliet Bembry for preparation of endothelial cells, and Dace Klimanis and Christl Reutzler for assistance with Western blots and TUNEL staining.

\section{References}

1. Tracey KJ, Cerami A. (1993) Tumor necrosis factor, other cytokines and disease. Ann. Rev. Cell Biol. 9: 317-342.

2. Rothwell NJ, Hopkins SJ. (1995) Cytokines and the nervous system II: action and mechanisms of action. Trends Neurosci. 18: 130-136.

3. Merril JE, Benveniste EN. (1996) Cytokines in inflammatory brain lesions: helpful and harmful. Trends Neurosci. 19: 331-338.

4. Barger S. (1998) Tumor necrosis factor, the good, the bad and the umbra. In: Mattson MP (ed.) Neuroprotective Signal Transduction. Humana Press, Totowa, NJ, pp. 163-183.

5. Hallenbeck JM. (1997) Cytokines, macrophages, and leukocytes in brain ischemia. Neurology 49(suppl 4): S5-9.

6. Mattson MP, Barger SW, Furukawa K, Bruce AJ, Wyss-Coray T, Mark RJ, Mucke L. (1997) Cellular signaling role of TGF beta, TNF alpha and beta APP in brain injury responses and Alzheimer's disease. Brain Res. Rev. 23: 47-61.

7. Barone FC, Feuerstein GZ. (1999) Inflammatory mediators and stroke: new opportunities for novel therapeutics. J. Cereb. Blood Flow Metab. 19: 819-834.

8. Shohami E, Ginis I, Hallenbeck JM. (1999) Dual role of tumor necrosis factor alpha in brain injury. Cytokine Growth Factor Rev. 10: 119-130. 
9. Shohami E, Novikov M, Bass R, Yamin A, Gallily R. (1994) Closed head injury triggers early production of TNF and IL- 6 by brain tissue. J. Cereb. Blood Flow Metab. 14: 615-619.

10. Taupin V, Toulmond S, Serrano A, Benavides J, Zavala F. (1993) Increase in IL-6, IL-1 and TNF levels in rat brain following traumatic lesion. Influence of pre- and post-traumatic treatment with Ro5 4864, a peripheral-type ( $p$ site) benzodiazepine ligand. J. Neuroimmunol. 42: 177-185.

11. Fan L, Young PR, Barone FC, Feuerstein GZ, Smith DH, McIntosh TK. (1996) Experimental brain injury induces differential expression of tumor necrosis factor- $\alpha$ mRNA in the CNS. Molec. Brain Res. 36: 287-291.

12. Liu T, Clark RK, McDonnel PC, Toung PR, White RF, Barone FC, Feuerstein FZ. (1994) Tumor necrosis factor-alpha expression in ischemic neurons. Stroke 25: 1481-1488.

13. Meirstrell ME III, Botchkina GI, Wang H, et al. (1997) Tumor necrosis factor is a brain damaging cytokine in cerebral ischemia. Shock 8: 341348.

14. Yamasaki T, Kikuchi H, Moritake K, et al. (1992) A morphological and ultrastructural investigation of normal mouse brain tissue after intracerebral injection of tumor necrosis factor. J. Neurosurg. 77: 279-287.

15. Uno H, Matsuyama $T$, Akita $H$, Nishimura $H$, Sugita M. (1997) Induction of tumor necrosis factor-alpha in the mouse hippocampus following transient forebrain ischemia. J. Cereb. Blood Flow Metab. 17: 491-499.

16. Dawson D, Martin D, Hallenbeck JM. (1996) Inhibition of tumor necrosis factor-alpha reduces focal cerebral ischemic injury in the spontaneously hypertensive rat. Neurosci. Lett. 218: 41-44.

17. Nawashiro H, Martin D, Hallenbeck JM. (1997) Inhibition of tumor necrosis factor ameliorated brain infarction in mice. J. Cereb. Blood Flow Metab. 17: 229-232.

18. Shohami E, Bass R, Wallach D, Yamin A, Gallily R. (1996) Inhibition of tumor necrosis factor (TNF-alpha) activity in rat brain is associated with cerebroprotecion after closed head injury. J. Cereb. Blood Flow Metab. 16: 378-384.

19. Shohami E, Gallily R, Mechoulam R, Bass R, Ben-Hur T. (1997) Cytokine production in the brain following closed head injury: dexanabinol (HU-211) is a novel TNF $\alpha$ inhibitor and an effective neuroprotectant. J. Neuroimmunol. 72: 169-177.

20. Leker R, Shohami E, Abramsky O, Ovadia H. (1999) Dexanabinol: a novel neuroprotective drug in experimental focal cerebral ischemia. J. Neurol. Sci. 162: 114-115.

21. Ito A, Horigome K. (1995) Ceramide prevents neuronal programmed cell death induced by nerve growth factor deprivation. J. Neurochem. 65: 463-466.
22. Goodman Y, Mattson MP. (1996) Ceramide protects hippocampal neurons against excitotoxic and oxidative insults, and amyloid beta-peptide toxicity. J. Neurochem. 66: 869-872.

23. Liu J, Ginis I, Spatz M, Hallenbeck JM. (2000) Hypoxic preconditioning protects cultured neurons against hypoxic stress via TNF- $\alpha$ and ceramide. Am. J. Physiol. (Cell Physiol.) 278: C144.

24. Ginis I, Schweizer U, Brenner M, Liu J, Azzam N, Spatz M, Hallenbeck JM. (1999) TNF- $\alpha$ pretreatment prevents subsequent activation of cultured brain cells with TNF- $\alpha$ and hypoxia via ceramide. Am. J. Physiol. (Cell Physiol.) 276: C1171-1183.

25. Halliwell B. (1992) Reactive oxygen species and the central nervous system. J. Neurochem. 59: 1609-1623.

26. Shohami E, Beit-Yannai E, Horowitz M, Kohen R. (1997) Oxidative stress in closed-head injury: brain antioxidant capacity as an indicator of functional outcome. J. Cereb. Blood Flow Metab. 17: 1007-1019.

27. Shohami E, Novikov M, Horowitz M. (1994) Long term exposure to heat reduces edema formation after closed head injury in the rat. Acta Neurochir. Suppl. (Wien) 60: 443-445.

28. Trembovler V, Beit-Yannai E, Younis F, Gallily R, Horowitz M, Shohami E. (1999) Antioxidants attenuate acute toxicity of tumor necrosis factoralpha induced by brain injury in rat. J. Interferon Cytokine Res. 19: 791-795.

29. Pogrebniak H, Matthews W, Mitchell J, Russo A, Samuni A, Pass H. (1991) Spin trap protection from tumor necrosis factor cytotoxicity. J. Surg. Res. 50: 469-474.

30. Kaltschmidt B, Sparna T, Kaltschmidt C. (1999) Activation of NF- $\kappa$ B by reactive oxygen intermediates in nervous system. Antioxidants Redox Signaling 1: 129-144.

31. Spatz M, Kawai N, Merkel N, Bembry J, McCarron RM. (1997) Functional properties of cultured endothelial cells derived from large microvessels of human brain. Am. J. Physiol. 272: C231-C239.

32. Ginis I, Faller DV. (1997) Protection from apoptosis in human neutrophils is determined by the surface of adhesion. Am. J. Physiol. 272: C295C309.

33. Ginis I, Mentzer SJ, Faller DV. (1995) Characterization of a hypoxia-responsive adhesion molecule for leukocytes on human endothelial cells. J. Immunol. 155: 802-810.

34. Ohara Y, McCarron RM, Hoffman TT, Sugano H, Bembrey J, Lenz FA, Spatz M. (in press) Adrenergic mediation of TNFa-stimulated ICAM-1 expression on human brain microvascular endothelial cells. Acta Neurochir.

35. Baeuerle PA. (1998) IkappaB-NF-kappaB structures: at the interface of inflammation control. Cell 95: 729-731. 
36. Beit-Yannai E, Zhang R, Trembovler V, Samuni A, Shohami E. (1996) Cerebroprotective effect of stable nitroxide radicals in closed head injury in the rat. Brain Res. 717: 22-28.

37. Love S. (1998) Oxidative stress in brain ischemia. Brain Pathol. 9: 119-131.

38. Beit-Yannai E, Kohen R, Horowitz M, Trembovler V, Shohami E. (1997) Changes in biological reducing activity in rat brain following closed head injury: a cyclic voltammetry study in normal and acclimated rats. J. Cereb. Blood Flow Metabol. 17: 273-279.

39. Feuerstein GZ, Wang X, Barone FC (1998). The role of cytokines in the neuropathology of stroke and neurotrauma. Neuroimmunomodulation 5: 143159.

40. Kamata H, Hirata H. (1999) Redox regulation of cellular signalling. Cell Signal 11: 1-14.

41. Schulze-Osthoff K, Bakker AC, Vanhaesebroeck B, Beyaert R, Jacob WA, Fiers W. (1992) Cytotoxic activity of tumor necrosis factor is mediated by early damage of mitochondrial functions. Evidence for the involvement of mitochondrial radical generation. J. Biol. Chem. 267: 5317-5323.

42. Lo YY, Cruz TF. (1995) Involvement of reactive oxygen species in cytokine and growth factor induction of c-fos expression in chondrocytes. J. Biol. Chem. 270: 11727-11730.

43. Schreck R, Rieber P, Baeuerle PA. (1991) Reactive oxygen intermediates as apparently widely used messengers in the activation of the NFkappa B transcription factor and HIV-1. EMBO J. 10: 2247-2258.

44. Rahman A, Kefer J, Bando M, Niles WD, Malik AB. (1998) E-selectin expression in human endothelial cells by TNF-alpha-induced oxidant generation and NF-kappaB activation. Am. J. Physiol. 275: L533-544.

45. Lo YYC, Wong JMS, Cruz TF. (1996) Reactive oxygen species mediate cytokine activation of c-Jun NH2-terminal kinases. J. Biol. Chem. 271: 15703-15707.

46. Tenneti L, D'Emilia DM, Troy CM, Lipton SA. (1998) Role of caspases in N-methyl-D-aspartateinduced apoptosis in cerebrocortical neurons. J. Neurochem. 71: 946-959.

47. Jornot L, Petersen H, Junod AF. (1997) Modulation of the DNA binding activity of transcription factors CREP, NFkappaB and HSF by $\mathrm{H} 2 \mathrm{O} 2$ and TNF alpha. Differences between in vivo and in vitro effects. FEBS Lett. 416: 381-386.

48. Bowie AG, Moynagh PN, O'Neill LAJ. (1997) Lipid peroxidation is involved in the activation of NF-kappaB by tumor necrosis factor but not interleukin-1 in the human endothelial cell line ECV304. Lack of involvement of $\mathrm{H} 2 \mathrm{O} 2$ in NF-kappaB activation by either cytokine in both primary and transformed endothelial cells. J. Biol. Chem. 272: 25941-25950.
49. Brennan P, O'Neill LA. (1995) Effects of oxidants and antioxidants on nuclear factor kappa $B$ activation in three different cell lines: evidence against a universal hypothesis involving oxygen radicals. Biochim. Biophys. Acta 1260: 167-175.

50. Israel N, Gougerot-Pocidalo MA, Aillet F, Virelizier JL. (1992) Redox status of cells influences constitutive or induced NF-kappa B translocation and HIV long terminal repeat activity in human $\mathrm{T}$ and monocytic cell lines. J. Immunol 149: 3386-3393.

51. Beg AA, Baltimore D. (1996) An essential role for NF-B in preventing TNF-induced cell death. Science 274: 782-784.

52. Wang C-Y, Mayo MW, Baldwin AS, Jr. (1996) TNF- and cancer therapy-induced apoptosis: potentiation by inhibition of NF-B. Science 274: 784-787.

53. Van Antwerp DJ, Seamus J, Martin SJ, Kafri T, Green DR, Verma IM. (1996) Suppression of TNFinduced apoptosis by NF-B. Science 274: 787-789.

54. Baichwal VR, Baeuerle PA. (1997) Activate NF-kappa B or die? Curr. Biol. 7: R94-96.

55. Lezoualc'h F, Sagara Y, Holsboer F, Behl C. (1998) High constitutive NF-kappaB activity mediates resistance to oxidative stress in neuronal cells. J. Neurosci. 18: 3224-3232.

56. Lezoualc'h F, Engert S, Berning B, Behl C. (2000) Corticotropin-releasing hormone-mediated neuroprotection against oxidative stress is associated with the increased release of non-amyloidogenic amyloid beta precursor protein and with the suppression of nuclear factor-kappaB. Mol. Endocrinol. 14: 147-159.

57. Kaltschmidt B, Uherek M, Wellmann H, Volk B, Kaltschmidt C. (1999) Inhibition of NF-kappaB potentiates amyloid beta-mediated neuronal apoptosis. Proc. Natl. Acad. Sci. USA 96: 9409-9414.

58. Heck S, Lezoualc'h F, Engert S, Behl C. (1999) Insulin-like growth factor-1-mediated neuroprotection against oxidative stress is associated with activation of nuclear factor kappaB. J. Biol. Chem. 274: 9828-9835.

59. Barger SW, Horster D, Furukawa K, Goodman Y, Krieglstein J, Mattson MP. (1995) Tumor necrosis factors alpha and beta protect neurons against amyloid beta-peptide toxicity: evidence for involvement of a kappa B-binding factor and attenuation of peroxide and $\mathrm{Ca} 2+$ accumulation. Proc. Natl. Acad. Sci. USA 92: 9328-9332.

60. Labarca C, Paigen K. (1980) A simple, rapid, and sensitive DNA assay procedure. Anal. Biochem. 102: 344-352.

61. Lennon SV, Martin SJ, Cotter TG. (1991) Dosedependent induction of apoptosis in human tumour cell lines by widely diverging stimuli. Cell Prolif. 24: 203-214.

62. Dypbukt JM, Ankarcrona M, Burkitt M, Sjoholm A, Strom K, Orrenius S, Nicotera P. (1994) 
Different prooxidant levels stimulate growth, trigger apoptosis, or produce necrosis of insulinsecreting RINm5F cells. The role of intracellular polyamines. J. Biol. Chem. 269: 30553-30560.

63. Hampton MB, Orrenius S. (1997) Dual regulation of caspase activity by hydrogen peroxide: implications for apoptosis. FEBS Lett. 414: 552556.

64. Shrivastava A, Aggarwal BB. (1999) Antioxidants differentially regulate activation of nuclear Factor-kB, activator protein-1, c-jun aminoterminal kinases, and apoptosis induced by tumor necrosis factor: evidence that JNK and NF-kB activation are not linked to apoptosis. Antioxidants Redox Signal. 1: 181-191.

65. Matthews JR, Hay RT. (1995) Regulation of the DNA binding activity of NF-kappa B. Int. J. Biochem. Cell Biol. 27: 865-879.

66. Sen CK, Packer L. (1996) Antioxidant and redox regulation of gene transcription. FASEB J. 10: 709-720.

67. Flohe L, Brigelius-Flohe R, Saliou C, Traber MG, Packer L. (1997) Redox regulation of NF-kappa B activation. Free Radic. Biol. Med. 22: 1115-1126.

68. Piette J, Piret B, Bonizzi G, Schoonbroodt S, Merville MP, Legrand-Poels S, Bours V. (1997) Multiple redox regulation in NF-kappaB transcription factor activation. Biol. Chem. 378: 12371245.

69. Sun SC, Ganchi PA, Ballard DW, Greene WC. (1993) NF-kappa B controls expression of inhibitor I kappa B alpha: evidence for an inducible autoregulatory pathway. Science 259: 1912-1915.

70. Kaltschmidt B, Uherek M, Volk B, Baeuerle PA, Kaltschmidt C. (1997) Transcription factor NFkappaB is activated in primary neurons by amyloid beta peptides and in neurons surrounding early plaques from patients with Alzheimer disease. Proc. Natl. Acad. Sci. USA 94: 2642-2647.

71. Singh I, Pahan K, Khan M, Singh AK. (1998) Cytokine-mediated induction of ceramide production is redox-sensitive. Implications to proinflammatory cytokine-mediated apoptosis in demyelinating diseases. J. Biol. Chem. 273: 2035420362.

72. Kaltschmidt C, Kaltschmidt B, Neumann H, Wekerle H, Baeuerle PA. (1994) Constitutive NF-kappa B activity in neurons. Mol. Cell Biol. 14: 3981-3992.

73. Furukawa K, Mattson MP. (1998) The transcription factor NF-kappaB mediates increases in cal- cium currents and decreases in NMDA- and AMPA/kainate-induced currents induced by tumor necrosis factor-alpha in hippocampal neurons. J. Neurochem. 70: 1876-1886.

74. Yu Z, Zhou D, Bruce-Keller AJ, Kindy MS, Mattson MP. (1999) Lack of the p50 subunit of nuclear factor-kappaB increases the vulnerability of hippocampal neurons to excitotoxic injury. J. Neurosci. 19: 8856-8865.

75. Botchkina GI, Geimonen E, Bilof ML, Villarreal O, Tracey KJ. (1999) Loss of NF-kappaB activity during cerebral ischemia and TNF cytotoxicity. Mol. Med. 5: 372-381.

76. Taglialatela G, Kaufmann JA, Trevino A, PerezPolo JR. (1998) Central nervous system DNA fragmentation induced by the inhibition of nuclear factor kappa B. Neuroreport 9: 489-493.

77. Sullivan PG, Bruce-Keller AJ, Rabchevsky AG, Christakos S, Clair DK, Mattson MP, Scheff SW. (1999) Exacerbation of damage and altered NFkappaB activation in mice lacking tumor necrosis factor receptors after traumatic brain injury. J. Neurosci. 19: 6248-6256.

78. Schneider A, Martin-Villalba A, Weih F, Vogel J, Wirth T, Schwaninger M. (1999) NF-kappaB is activated and promotes cell death in focal cerebral ischemia. Nat. Med. 5: 554-559.

79. Yang K, Mu XS, Hayes RL. (1995) Increased cortical nuclear factor-kappa B (NF-kappa B) DNA binding activity after traumatic brain injury in rats. Neurosci. Lett. 197: 101-104.

80. Hickenbottom SL, Grotta JC, Strong R, Denner LA, Aronowski J. (1999) Nuclear factor-kappaB and cell death after experimental intracerebral hemorrhage in rats. Stroke 30: 2472- 2477 (discussion, 2477-8).

81. Carroll JE, Howard EF, Hess DC, Wakade CG, Chen Q, Cheng C. (1998) Nuclear factor-kappa $B$ activation during cerebral reperfusion: effect of attenuation with $\mathrm{N}$-acetylcysteine treatment. Brain Res. Mol. Brain Res. 56: 186-191.

82. Clemens JA, Stephenson DT, Yin T, Smalstig EB, Panetta JA, Little SP. (1998) Drug-induced neuroprotection from global ischemia is associated with prevention of persistent but not transient activation of nuclear factor-kappaB in rats. Stroke 29: 677-682.

83. Manna SK, Zhang HJ, Yan T, Oberley LW, Aggarwal BB. (1998) Overexpression of manganese superoxide dismutase suppresses tumor necrosis factor-induced apoptosis and activation of nuclear transcription factor-B and activated protein-1. J. Biol. Chem. 273: 13245-13254. 